\title{
SUBACUTE SCLEROSING PANENCEPHALITIS WITH ATYPICAL CLINICAL AND MRI FINDINGS
}

\author{
Buse Rahime HASIRCI, Dilek AĞIRCAN, Münevver OKAY, Asuman ORHAN VAROĞLU, Abdulkadir KOÇER \\ İstanbul Medeniyet University Göztepe Research and Training Hospital, Neurology Department, \\ ISTANBUL, TURKEY
}

\begin{abstract}
Subacute sclerosing panencephalitis (SSPE) is a progressive inflammatory disorder of the central nervous system and a slow virus infection caused by aberrant measles virüs. Typical neurological manifestations include psychomotor impairment, progressive intellectual deterioration, myoclonic jerks and behavioral changes, with or without pyramidal symptoms. It usually affecting people aged 10 to 14 year. We report the case of an 17-year-old girl presenting with initial symptom of visual loss, seizures, a lack of SSPE specific EEG pattern, late onset and atypical fast progression of disease. The case highlights the importance of atypical clinical findings of SSPE at onset and also firstly disappearing, then appearing MRI findings at sequential images which can complicate the accurate diagnosis. High suspicion is needed because of its rareness.
\end{abstract}

Key Words: Subacute Sclerosing Panencephalitis, measles, magnetic resonance imagıng, atypical findings, nonspesific EEG

\section{ATIPIK KLINIIK VE MR BULGULARI OLAN SUBAKUT SKLEROZAN PANENSEFALİT VAKASI}

\section{ÖZET}

Subakut sklerozan panensefalit(SSPE) santral sinir sistemini etkileyen progresif, enflamatuar bir hastalıktır ve kızamık virusunun neden olduğu yavaş virüs enfeksiyonudur. Tipik nörolojik bulgular psikomotor bozukluk, ilerleyici zeka bozukluğu, myoklonik jerkler ve davranıș değișikliği, bazen de piramidal semptomlardır. 10-14 yaş arası çocukları etkiler. Biz görme kaybı, nöbetler ve nonspesifik EEG bulguları ile prezente olan 17 yaşında geç başlangıçlı, hızlı progresyon gösteren atipik bir SSPE vakası sunmayı amaçladık. Bu vaka atipik klinik bulguları ve başlangıçta görülmeyip sonradan ortaya çıkan MR bulguları nedeniyle tanıda şüphelenilmesi gerekliliğine dikkat çekmektedir.

Anahtar Sözcükler: Subakut sklerozan panensefalit, kızamık virüsü, MR görüntüleme, atipik bulgular, Nonspesifik EEG

\section{INTRODUCTION}

Subacute sclerosing panencephalitis (SSPE) is a progressive inflammatory disorder of the central nervous system (CNS). It occurs in an incidence of 1 per 100,000 to 500,000 measles cases, usually affecting people aged 10 to 14 year [1,2]. Typical neurological manifestations include psychomotor impairment, progressive intellectual deterioration, myoclonic jerks and behavioral changes, with or without pyramidal symptoms [3]. Although there are reports of prolonged spontaneous remission, after the generalized convulsions over the months or years, dementia, coma and death occurs in most patients within 1-3 years [4].

\section{CASE}

A healthy 17 year old girl was admitted to the neurology clinic with a four month history of visual disturbances and blurred vision. Cranial magnetic resonance imaging (MRI) taken during that period was normal but her vision complaints has been progressed. After three months of visual diturbances, second cranial MRI was done. It revealed high signal intensity and vasogenic edema at the bilateral occipital lobes (Figure 1). Digital Subtraction Angiography (DSA) showed multilocular narrowing of large- and medium-sized vessels. She was diagnosed as vasculitis and steroid (750 mg/day) therapy was given for 3 weeks.

\footnotetext{
Corresponding author: Dr. Dilek Ağırcan. İstanbul Medeniyet University Göztepe Research and Training Hospital, Neurology Department, İstanbul. Turkey. Phone: +902165664000 E-mail: d_agircan@hotmail.com

Received: 19.10.2014 Accepted: 08.01.2015

This article should be cited as following: Hasirci B. R, Ağırcan D, Okay M, Orhan Varoğlu A, Koçer A. Subacute sclerosing panencephalıtis with atypical
} clinical and MRI findings. Turkish Journal of Cerebrovascular Diseases 2016; 22 (1): 25-28. doi:10.5505/tbdhd.2016.94824. 


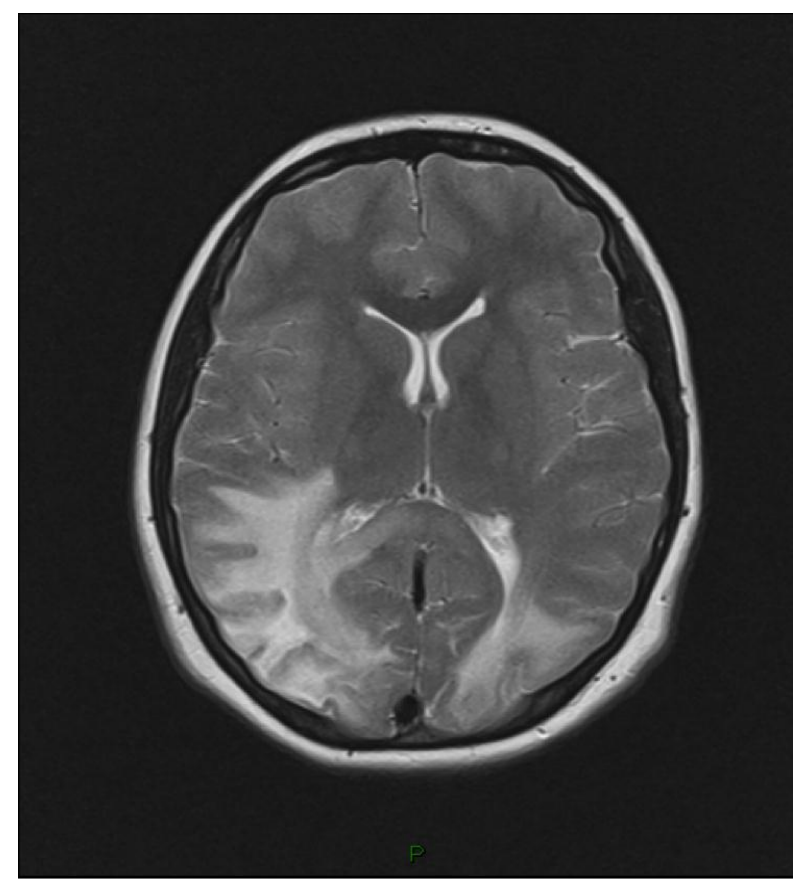

Figure 1. MRI revealed high signal intensity and vasogenic edema at the bilateral occipital lobes.

After the therapy, third cranial MRI revealed appearance of new left temporal lobe lesions (Figure 2). Lymphoma was considered as the second diagnosis.

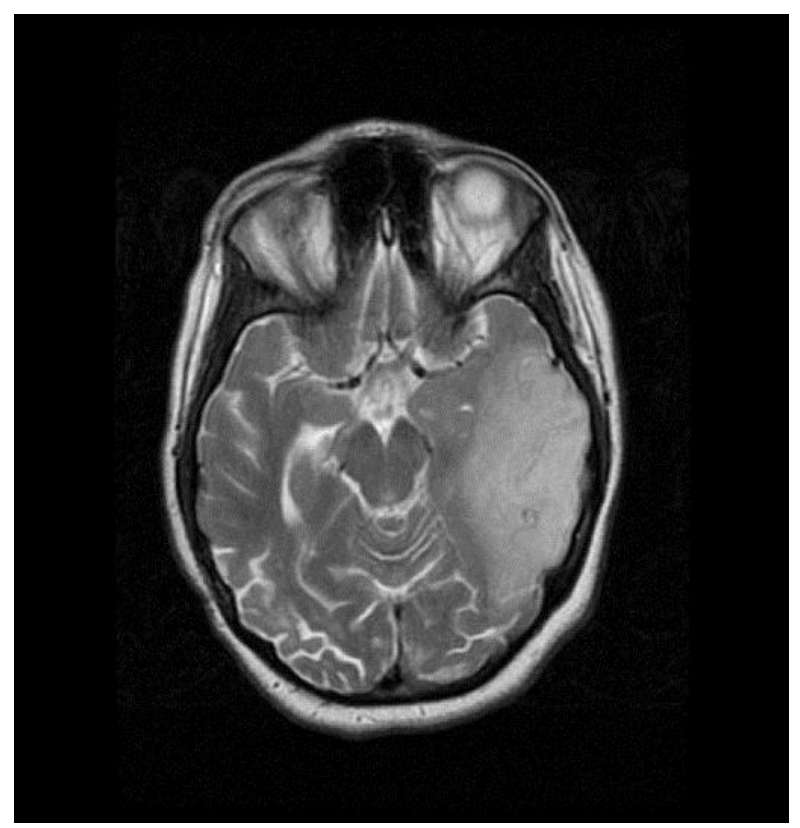

Figure 2. MRI revealed appearance of new left temporal lobe lesions.
She was hospitalized for further investigations. Her developmental milestones were normal and there was no family background of neurological disorders. In her neurological examination, cranial nerves were normal and meningeal signs were absent. Visual acuity decreased in both eyes (20/800) and optic disks were atrophic. On mental status examination, there was a progressive impairment with learning, long term memory recording, sustaining attention and word formation. At following days, she was confused and agitated. Myoclonic jerks appeared. Because of typical MRI lesions and clinical findings, SSPE has been thought as diagnosis. A complete blood count, erythrocyte sedimentation rate, biochemical parameters, including urea, creatinine, blood sugar, electrolytes, lipid profile, liver function tests and vasculitis markers, paraneoplastic neuronal antibodies, NMO antibody and GAD antibody tests were all within normal limits. Cerebrospinal fluid (CSF) biochemistry, lactic acid and microbial analysis were normal. CSF opening pressure was $38 \mathrm{cmH} 20$. CSF serology for herpes simplex type1-2, tuberculosis and atypical cells were all negative. There was no infection and malignancy in thorax tomography. Because of previous cranial MRI and DSA findings, asetazolamide $\quad 500 \quad \mathrm{mg} /$ day and methylprednisolone (750 $\mathrm{mg} /$ day) intravenously for 15 days were administrated. Despite the treatment, her complaints were not declined and new posterior lesions were seen in MRI findings (Figure 3). The brain biopsy revealed perivascular infiltration, microglial activity and neuronal atrophy which were especially specific for SSPE, HIV and prion diseases. This clinical picture was followed by seizures around the mouth and right side of the body. EEG was done and showed periodic (3-4 times in 10 second) epileptiform discharges in left hemisphere. A repeat EEG done after diazem injection, not revealed suppression.

She became unresponsive and right side hemiplegia developed. Recurrent seizures and myoclonic movements led to prescription of levatiracetam, oxcarbazepine combined with clonazepam. Although the patient did not have any prior history of measles infection, a new lumber puncture was done. CSF analysis showed measles immunoglobulin $\mathrm{G}$ index was 9.53 (normal value<1.3), globulin levels $(26 \mathrm{mg} / \mathrm{dl})$ were greater than $20 \%$ of total CSF protein $(35 \mathrm{mg} / \mathrm{dl})$. 


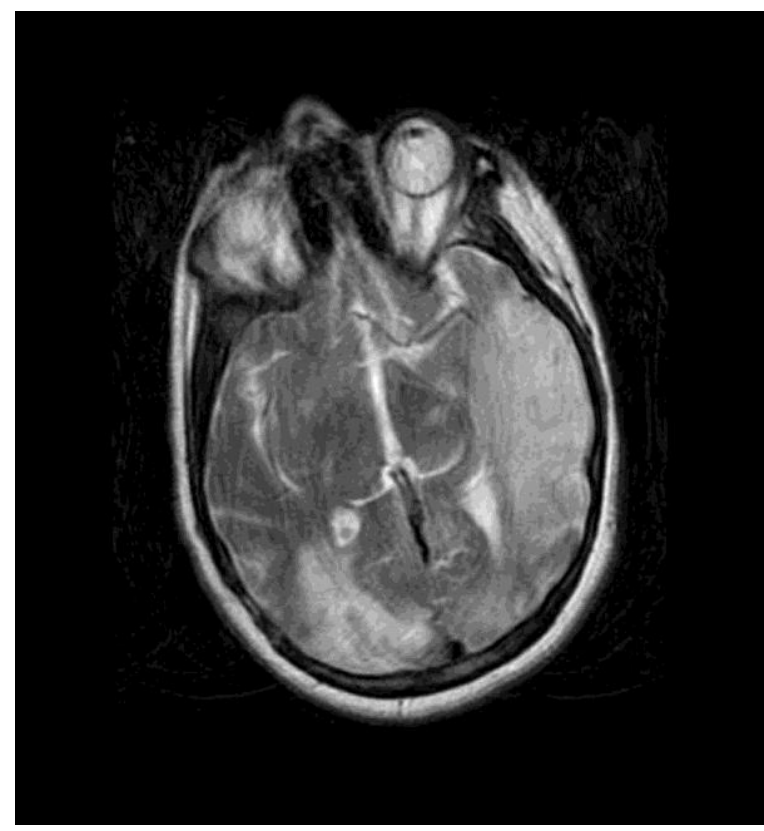

Figure 3. MRI showed new bilateral posterior lesions.

The patient was diagnosed as SSPE and Isoprinosine was administered. Oxcarbazepine was stopped, and valproate was administered. The frequency and duration of the miyoclonic jerks were significantly shortened. However, after two months of continuous follow up, patient did not show any improvement in cognitive functions and died four months after the onset of the disease.

\section{DISCUSSION}

Our patient had characteristic clinical findings and laboratory test results to confirm the diagnosis of SSPE. She presented with visual loss and cognitive impairment shortly followed by myoclonic jerks. Her CSF globulin levels greater than 20\% of total CSF protein and measles antibodies titers raised in blood and CSF. The most important part of her findings were atypical MRI findings and clinical onset with visual loss and optic atrophy. SSPE was diagnosed through the clinical presentation and magnetic resonance imaging (MRI).

Brain biopsy performed in the early stages of SSPE shows mild inflammation of the meninges and brain parenchyma involving cortical and subcortical grey matter as well as white matter. There is often evidence of neuronal degeneration, gliosis, proliferation of astrocytes, perivascular cuffing, lymphocytic and plasma cell infiltration, and demyelination [4]. Similarly brain biopsy of our patient showed perivascular infiltration, microglial activity and neuronal atrophy which were specific for viral infections.

Atypical form of SSPE occurs in about $10 \%$ of all patients and there are no defined stages in clinical presentation due to rapid course [5]. Atypical features include unusual age of onset, visual loss, seizures and other focal symptoms as initial presentations, a lack of SSPE-specific EEG pattern, and atypical fast progression of disease [6]. While ophthalmological symptoms such as optic atrophy, chorioretinitis, and papilledema are commonly associated with SSPE [4-7]. However, the presentation of vision loss preceding neurological symptoms is rare [7] as in our patient.

One of the most important limitations in treatment of SSPE is difficulty in recognising early clinical findings of disease, when the inflammatory changes are, possibly, still reversible [4]. Although no treatment has proven effective, oral isoprinosine and intrathecal administration of alfa interferon may prolong survival [8].

Neuro-imaging characteristic of SSPE patients are typical and MRI is the best radiological imaging method for SSPE. Generally, MRI is normal at the onset of the disease. MRI reveals well-defined hyperintensity areas observed on T2-weighted images in the early stage. In advanced stages, signal changes in deep white matter and cerebral atrophy are observed.[4] The parieto-occipital region is most frequently affected and the involvement is generally asymmetric [9] as observed in our patient. MRI is the best method for detecting abnormalities in SSPE. It is important to follow sequential images due to obtain accurate diagnosis. Although, there are few reports of atypical clinical findings of SSPE, to our knowledge there have been no case of reversible disappearing and again appearing lesions on MRI of SSPE.

\section{REFERENCES}

1. Dyken PR. Subacute sclerosing panencephalitis: current status. Neurol Clin. 1985;3:179-196.

2. Honarmand S, Glaser CA, Chow E et al. Subacute sclerosing panencephalitis in the differential diagnosis of encephalitis. Neurology. 2004;63:1489-93.

3. Salehi HR, Delgado E, Wolf SM et al. Subacute sclerosing panencephalitis with atypical features. Pediatr Neurol. 2005;33:280-2.

4. Garg RK. Subacute sclerosing panencephalitis. Review. Postgrad Med J. 2002; 78:63-70. 
5. Kravljanac R, Jovic N, Djuric $M$ et al. Epilepsia partialis continua in children with fulminant subacute sclerosing panencephalitis. NeuroloSci. 2010;32:1007-12.

6. Cruzeiro MM, Vale TC, Pires LA et al. Atypical subacute sclerosing panencephalitis. Arq Neuropsiquiatr. 2007;65(4A):1030-33.

7. Kirk J, Zhou A-L, McQuaid S et al. Cerebral endothelial cell infection by measles virus in subacute sclerosing panencephalitis: ultrastructural and in situ hybridization evidence. Neuropathol Appl Neurobiol. 1991;17:289-97.
8. Gascon G, Yamani S, Crowell J et al. Combined oral isoprinosine-intra- ventricular alfa-interferon therapy for subacute sclerosing panencephalitis. Brain Dev. 1993;15:346-55.

9. Alkan A, Sarac K, Kutlu R et al. Early and late-state subacute sclerosing panencephalitis: chemical shift imaging and single-voxel MR spectroscopy. AJNR Am J Neuroradiol. 2003;24:501-6. 